\title{
Prenatal diagnosis and postnatal treatment with bleomycin of fetal axillary cystic hygroma
}

\author{
Aslıhan Yazıcıoğlu, Mert Turğal, Özge Senem Yücel, Özgür Özyüncü \\ Department of Obstetrics \& Gynecology, Faculty of Medicine, Hacettepe University, Ankara, Turkey
}

\begin{abstract}
Objective: Fetal cystic hygroma is a rare congenital malformation of the lymphatic system, characterized by the formation of a multilocular cystic mass in different parts of the fetal body. Expectant management, aspiration, surgery and the use of sclerosing agents are the current treatment options available today. Herein, we discussed a case of fetal axillary cystic hygroma with its antenatal follow-up and successful postnatal treatment with sclerotherapy.

Case: In this report, we present a case of fetal axillary cystic hygroma diagnosed antenatally at 32nd weeks of gestation followed by full-term delivery in a 30-year-old woman. During postnatal follow up, bleomycin sclerotherapy was performed. The result was excellent with good cosmetic result.

Conclusion: Since it affects the timing of birth and requires tertiary postnatal care, prenatal diagnosis of fetal cystic hygroma is very important.

Key words: Fetal cystic hygroma, prenatal diagnosis, bleomycin sclerotherapy.
\end{abstract}

\section{Introduction}

Cystic hygroma is a congenital malformation of the lymphatic system appearing as large multiloculated fluid-filled cavities located predominantly in the neck region. ${ }^{[1,2]}$ It has been associated with fetal chromosomal abnormalities, Turner's syndrome being the most common, hydrops fetalis and structural malformations. ${ }^{[3]}$

The treatment modality depends on the clinical picture, lesion size, anatomic location and related com-
Prenatal diagnosis and postnatal treatment with bleomycin of fetal axillary cystic hygroma

Amaç: Fetal kistik higroma, lenfatik sistemin nadir bir konjenital malformasyonu olup fetal vücudun değişik kısımlarında multiloküle kistik kitle oluşumu ile karakterizedir. Beklegör yönetimi, aspirasyon, cerrahi ve sklerozan ajan kullanımı günümüzde mevcut tedavi seçenekleri arasında yer almaktadır. Burada, bir fetal aksiller kistik higroma olgusunun antenatal takibi ve postnatal dönemde skleroterapi ile başarılı tedavisi tartışılması amaçlanmıştır.

Olgu: Otuz yaşındaki gebenin, gebeliğinin 32. haftasında tanı alan bir fetal aksiller kistik higroma olgusu saptand. Postnatal izlemde bleomisin ile skleroterapi uyguland. Sonuç, iyi kozmetik sonuç ile birlikte mükemmeldi.

Sonuç: Doğum zamanlamasını etkilemesi ve tersiyer postnatal bakım gerektirmesi nedeniyle, fetal kistik higromanın prenatal tanısı önem taşımaktadır.

Anahtar sözcükler: Fetal kistik higroma, prenatal tanı, bleomisin skleroterapi.

plications. While surgery is the treatment of choice, this is very difficult to perform in some cases due to the infiltrative nature of the lesion to adjacent vital structures. Complete excision can not always be accomplished and recurrences commonly occur after surgery. ${ }^{[4]}$ The patient can be affected by several morbid conditions such as nerve injuries, prolonged lymphatic drainage, recurrence, wound infections, unacceptable scar formation and incomplete resection due to infiltration of surrounding vital structures. ${ }^{[2]}$ In recent years, two sclerosing agents, bleomycin and OK-432,
Correspondence: Aslıhan Yazıcığlu, MD. Hacettepe Üniversitesi Tıp Fakültesi, Kadın Hastalıkları ve Doğum Anabilim Dalı, Ankara, Turkey.

e-mail: draslihanakar@hotmail.com

Received: January 7, 2013; Accepted: April 22, 2013
Available online at: www.perinataljournal.com/20130212010 doi: $10.2399 /$ prn.13.0212010 QR (Quick Response) Code: 
have been favored by some surgeons for the treatment of cystic hygroma. ${ }^{[4]}$

Herein, we present a case of antenatally diagnosed fetal axillary cystic hygroma, postnatal treatment with bleomycin sclerotherapy and excellent post-treatment result.

\section{Case Report}

A 30-year-old woman, gravida 3, parity 2 was referred to our hospital at 32 weeks of gestation because of a mass on the left fetal axilla detected by routine ultrasonography performed at a hospital. The patient's family history and previous medical history were unremarkable and there were no consanguinity between parents. In the current pregnancy, 1st trimester biochemical screening and the maternal serum $\alpha$-fetoprotein checked at 16 weeks of gestation were both normal. Second trimester fetal anomaly screening ultrasound performed at 20 weeks of gestation was also normal.

Ultrasound examination, performed in our hospital at 32 weeks of gestation, revealed a $5 \times 6 \mathrm{~cm}$-sized, multiseptated cystic mass which was extending to the anterior and posterior thoracic wall in the left axillary region of the fetus. There was no evidence of intrathoracic extension of mass. Other fetal sonographic biometric indices and amniotic fluid amount were normal and no other structural abnormalities were found with normal echocardiography in the fetus. Prenatal karyotyping was not offered due to the advanced gestational age at admission. A provisional diagnosis of cystic hygroma was made.

Sonography was repeated at 36 weeks of gestation and revealed a normal fetal growth and no change in size of the mass. Cesarean section was performed at 38 weeks of gestation due to rupture of membranes accompanying breech presentation and hyperabduction of the left arm. A 3210 grams of weight female infant was delivered with Apgar scores of 9 and 10 at $1 \mathrm{~min}$ and 5 min, respectively. On delivery, the baby demonstrated a $5 \times 5 \mathrm{~cm}$-sized, soft cystic mass in the left axillary region (Fig. 1). The baby did not have any other structural anomalies. Peripheral blood karyotype was normal, 46,XX. Postnatal chest magnetic resonance imaging was performed a month after delivery and revealed a $8 \times 3 \times 5 \mathrm{~cm}$-sized macrocystic mass which was extending to the anterior and posterior thoracic wall, with contrast-enhancing septa (Fig. 2). The mass did not have intrathoracic extension but had close proximity brachial

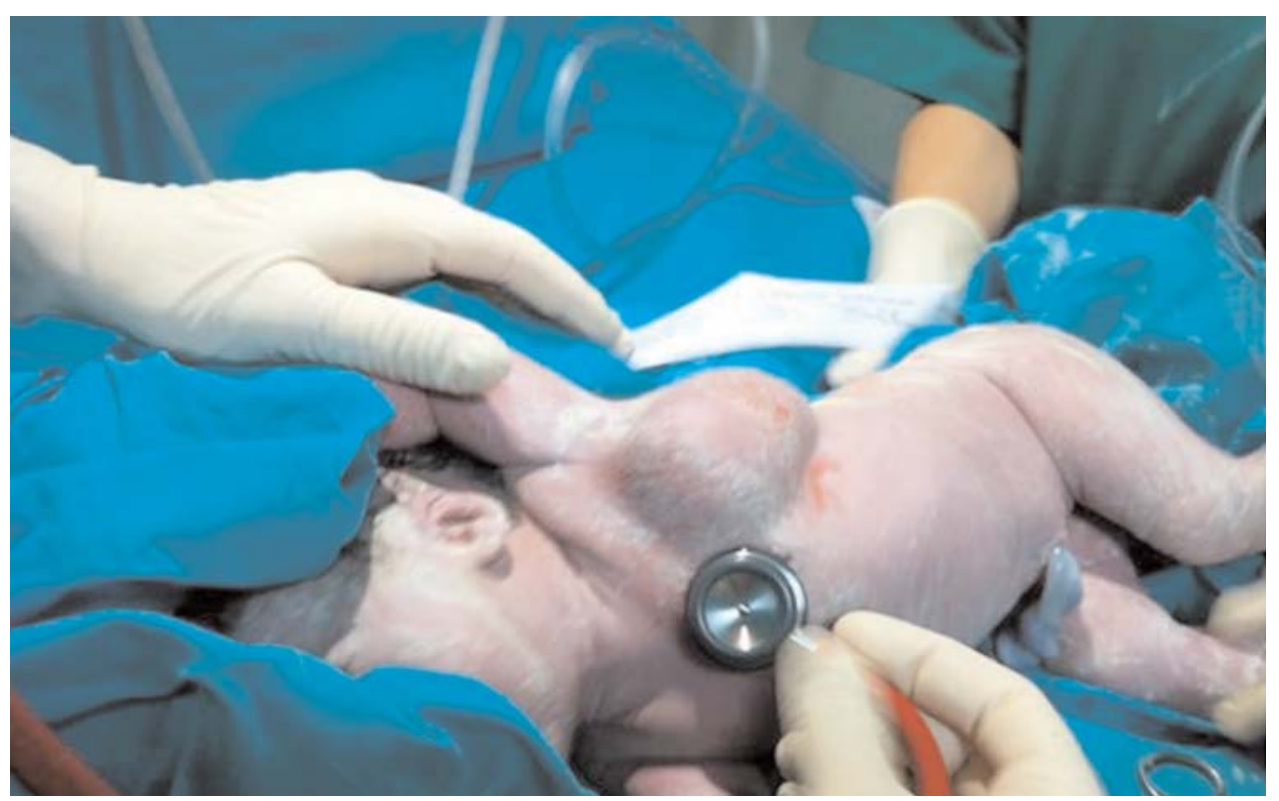

Fig. 1. The fetus during delivery. In the clinical picture taken during delivery, $5 \times 5 \mathrm{~cm}$ sized, soft cystic mass causing hyperabduction of the arm is seen on the left axillary region. 


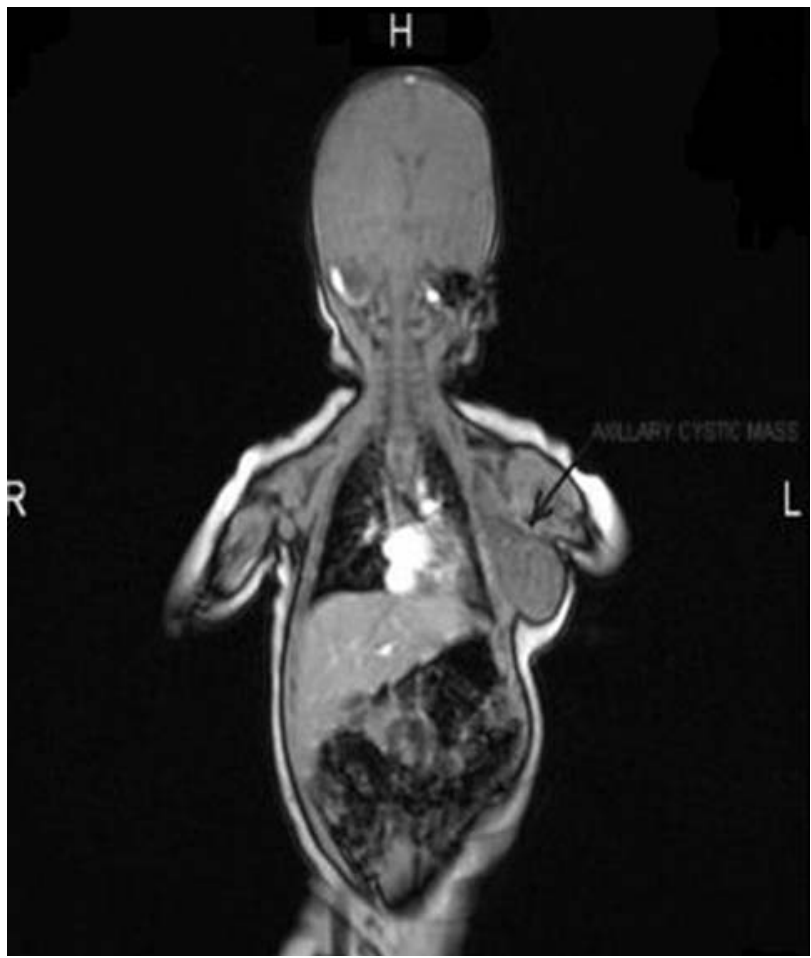

Fig. 2. Axillary mass in fetal MRI. Coronal MR images with contrast reveals a $8 \times 3 \times 5 \mathrm{~cm}$-sized macrocystic mass which is extending to the anterior and posterior thoracic wall, with contrast-enhancing septa.

plexus. Due to the nature of the cystic mass, the probability of incomplete resection, related recurrences and nerve injury, pediatric surgeons performed bleomycin sclerotherapy. The result was excellent, no complications related to bleomycin were seen and the patient has no residual disease 6 months after therapy.

\section{Discussion}

Fetal cystic hygroma is a congenital malformation in which distended fluid-filled cavities develop, mostly in the fetal neck region, resulting from developmental anomaly of the lymphatic system. ${ }^{[3]}$ The incidence of cystic hygroma is 1 in 6,000 births, but it is a relatively common anomaly in miscarried fetuses, with a frequency of $1: 875 .^{[5]}$

Cystic hygroma shows postnatal anatomic variability. $75 \%$ found in the neck, mainly the posterior triangle, with a predilection for the left side, and 20\% localized in the axillary region. ${ }^{[2]}$ The other rare locations are mediastinum, groin and retroperitoneum.
The frequency of chromosomal abnormalities associated with cystic hygroma is high (78\%), the most common one is Turner's syndrome. ${ }^{[5]}$ Trisomies, cardiac anomalies, hydrops fetalis and Noonan syndrome also have association with this congenital malformation. ${ }^{[6]}$ Our case showed a normal karyotype. When a cystic hygroma diagnosed antenatally, serial ultrasound examination is recommended. ${ }^{[5]}$ Other recommendations are the research for cardiac, renal anomalies and signs of hydrops fetalis.

The prognosis depends on several variables such as karyotype, location of the mass, gestational week of diagnosis, depth of invasion, and presence of septations. $^{[3,5]}$ Our case was first established in the late third trimester, with a fist-sized septated cystic mass localized to the axillary region without intrathoracic extension. Since these benign lesions have a potential of growth, serial ultrasonographic measurements are important in timing and mode of delivery. In small isolated cystic hygroma cases, there is no need to modify standard obstetrical management. ${ }^{[3]}$ When large lesions are present, a cesarean section may be advisable. ${ }^{[3]}$ Masood et al. reported dystocia during birth of the fetal body. ${ }^{[6]}$ Since our case had a large mass along with the abduction of arm, the patient was counseled about dystocia and cesarean section was performed.

In the medical literature, there are many different treatment options, but among these, surgery and the use of sclerosing agents should be mentioned. Since these lesions usually infiltrates the adjacent vital structures such as nerves and vessels, surgical excision would result in inadvertent nerve and vessel injury and residual disease. Afterward, residual disease may lead to wound infections, recurrences and bad cosmetic results. Another treatment option, intralesional sclerosing agents have been suggested for cystic hygroma. In 1966, Umezawa discovered the chemotherapeutic agent, bleomycin. ${ }^{[4]}$ Yura et al. reported the first satisfactory results of intralesional bleomycin injection in 1977. ${ }^{[7]}$ Niramis et al. also suggested that bleomycin would be more effective in single superficial and large cystic lesions allowing easy aspiration. ${ }^{[4]}$ Partial reduction is also valuable, since reduction in the mass, simplifies the excisional surgery. ${ }^{[8]}$ Niramis et al. reported transient swelling, pain, fever, redness at the side of injection and leukopenia within 24-48 hours after injection. ${ }^{[4]}$ Because of temporary bone marrow suppression, dose reduction in infants may be advisable. 


\section{Conclusion}

Prenatal diagnosis of fetal cystic hygroma is very important in the management of these patients. Timed delivery and postnatal follow up are crucial in prognosis. Surgeons should keep in mind not only the alternative therapy with intralesional bleomycin injection in selected cases but also the treatment-related side effects.

Conflicts of Interest: No conflicts declared.

\section{References}

1. Burezq H, Williams B, Chitte SA. Management of cystic hygromas: 30 year experience. J Craniofac Surg 2006;17:815-8.

2. Baskin D, Tander B, Bankaoğlu M. Local bleomycin injection in the treatment of lymphangioma. Eur J Pediatr Surg 2005;15:383-6.
3. Temizkan O, Abike F, Ayvaci H, Demirag E, Görücü Y, Isik E. Fetal axillary cystic hygroma: a case report and review. Rare Tumors 2011;3(4):e39.

4. Niramis R, Watanatittan S, Rattanasuwan T. Treatment of cystic hygroma by intralesional bleomycin injection: experience in 70 patients. Eur J Pediatr Surg 2010;20:17882.

5. Song TB, Kim CH, Kim SM, Kim YH, Byun JS, Kim EK. Fetal axillary cystic hygroma detected by prenatal ultrasonography: a case report. J Korean Med Sci 2002;17:400-2.

6. Masood SN, Masood MF. Case report of fetal axillo-thoraco-abdominal cystic hygroma. Arch Gynecol Obstet 2010;281:111-5.

7. Yura J, Hashimoto T, Tsuruga N, Shibata K. Bleomycin treatment for cystic hygroma in children. Nihon Geka Hokan 1977;46:607-14.

8. Uslu T, Koç A, Ortaç F, Dündar İ. Fetal kistik higroma. T Klin Jinekol Obst 1992;2:109-11. 